\title{
Peranan Advokat Dalam Pembelaan Hukum terhadap Terdakwa Korupsi di Pengadilan Tindak Pidana Korupsi pada Pengadilan Negeri Samarinda (Tinjauan Etika Profesi Hukum)
}

\author{
Jaidun \\ Jaidundosenuwgm@gmail.com \\ Dosen Fakultas Hukum Universitas Widya Gama Mahakam Samarinda
}

\begin{abstract}
ABSTRAK
Orang cerdas dan beriman, tidak akan pernah membantah, bahwa Negera Republik Indonesia ini hancur berantakan, utang-utang menggunung, hingga menembus angka Rp. 4.000 (Empat Ribu) Triliun adalah karena kejahatan korupsi yang sudah mengakar, menggurita, tumbuh subur seolah-olah dibiarkan terjadi terus-menerus. Sementara penegakan hukum di negeri ini tidak memberikan vonis hukumqan yang menimbuilkan efek jera bagi pelaku korupsi. Sulit dipahami secara awam, apakah vonis hukum bagi pelaku korupsi oleh Majelis Hakim yang menyidangkan dan memutuskan perkara tindak pidana korupsi tersebut dipengaruhi oleh adanya campur tangan dari sesama penegak hukum..?, dalam hal ini Advokat dan Jaksa Penuntut Umum (JPU). Putusan Pengadilan tindak pidana korupsi jutsru sering terjadi disparitas putusan, sehingga menimbulkan spekulasi dari publik dan menilai putusan yang demikian itu cendrung tidak proporsional dan melahirkan asumsi publik adanya persengkongkolan antara para penegak hukum, yaitu dengan beberapa kategori kepentingan, antara lain: (1) Kepentingan JPU dan Hakim adalah kepentingan mendapatkan uang suap (2) Advokat sebagai penegak hukum yang mendampingi terdakwa demi membela kepentingan terdakwa dengan cara suap-menyuap yang kotor dan menjijikan.

Pernanan advokat sangat penting dalam menciptakan dan memelihara sistem peradilan yang bersih, berwibawa dan beradab demi terwujudnya wibawa hukum di negeri ini. Maka demikian, advokat hukum harus memiliki keimanan dan ketaqwaan kepada Allah ta'ala yang kuat dan kokoh serta harus berani tampil bersih dan terlebih dahulu membersihkan diri dari pikiran-pikiran kotor ditengah-tengah menjalankan profesi hukum, agar profesi mulia tersebut tidak tercemar menjadi hina akibat pelanggaran norma hukum dan kode etik profesi oleh advokat.

Berdasarkan hasil yang out-put yang dicapai dalam program penelitian ini yaitu kemauan dan kedasaran para Advokat dalam membela kepentingan terdakwa harus sesuai ketentuan hukum dan Peraturan Perundang-undangan yang berlaku serta menjunjung tinggi Kode Etik Prosesi.

Analisis dari tulisan ini menunjukan, bahwa advokat sudah melakukan pembelaan hukum terhadap terdakwa korupsi secara professional sesuai ketentuan hukum yang berlaku dan menjunjung tinggi kode etik profesi hukum, meskpun ada juga informasi tentang salah seorang advokat yang berusaha menyuap salah seorang hakim Tindak Pidana Korupsi dalam suatu perkara yang sedang ditangani oleh Advokat yang bersangkutan. Gambaran dari hasil kegiatan survey ini diharapkan dapat dijadikan masukan dan saran yang dapat membantu mewujudkan putusan Pengadilan yang menimbulkan efek jera bagi pelaku korupsi maupun calon pelaku korupsi dimasa yang akan datang.
\end{abstract}

\section{Kata kunci : Peranan dan Kode Etik Profesi Advokat, tuntutan Jaksa Penuntut Umum,} Putusan Pengadilan Tindak Pidana Korupsi Samarinda. 


\begin{abstract}
Smart and faithful people, will never argue, that the State of the Republic of Indonesia is falling apart, debts mounting, to the point of reaching Rp. 4,000 (Four Thousand) Trillion is due to the crime of corruption that has taken root, curbed, thrived as if allowed to happen continuously. While law enforcement in this country does not provide a judicial verdict that has a deterrent effect for corruptors. It is difficult to understand in general, whether the legal verdict for corruption perpetrators by the Panel of Judges who hear and decide the case of corruption is influenced by the interference of fellow law enforcers ..., in this case, Advocates and Public Prosecutors (Prosecutors).

Decisions of Corruption Courts often cause disparity in decisions, resulting in speculation from the public and assessing such decisions as being disproportionate and giving rise to public assumptions of a conspiracy between law enforcers, namely with several categories of interests, including: (1) The interests of the Prosecutor and Judges are in the interest of getting bribes (2) Advocates as law enforcers who accompany the defendant in defence of the interests of the accused by dirty and disgusting bribes. The role of advocates is very important in creating and maintaining a clean, authoritative and civilized justice system for the realization of the legal authority in this country.

Thus, legal advocates must have faith and devotion to God strong and sturdy table and must dare to appear clean and first cleanse themselves from dirty thoughts in the midst of carrying out the legal profession, so that the noble profession is not polluted into contempt resulting from violation of legal norms and professional code of ethics by advocates. Based on the outputs achieved in this research program, namely the willingness and bottomlessness of the Advocates in defending the interests of the defendant must comply with the provisions of the applicable laws and regulations and uphold the Code of Ethics Procession.

The analysis of this paper shows that lawyers have made a legal defence of corruption defendants in a professional manner in accordance with applicable legal provisions and upholds the code of ethics of the legal profession, even though there is also information about an advocate who is trying to bribe one of the Corruption Crimes judges in a case. which is being handled by the Advocate concerned. The description of the results of this survey is expected to be used as input and advice that can help realize the Court's decision which has a deterrent effect on corruptors and potential corruptors in the future.
\end{abstract}

Keywords: Role and Code of Ethics of the Professional Advocate, demands of the Public Prosecutor, Decision of Samarinda Corruption Criminal Court.

\title{
PENDAHULUAN
}

\section{A. Latar Belakang}

The Founding Fathers meletakan pondasi Negara Indonesia dengan sebuah cita-cita mulia yaitu Negara hukum (Rechstaat/The Rule of law), bukan negara berdasarkan kekuasaan. Pasal 1 ayat (3) UUD 45, menegaskan, bahwa, Negara Indonesia adalah negara hukum. Cita-cita mulia pendiri negari ini menjadikan Indonesia sebagai negara hukum hanya sebuah cita-cita dan harapan, karena hingga kini (Rezim Reformasi) penegakkan hukum

masih memiliki problematika dalam konteks implementasi hukum, karena aparat penegak hukum belum maksimal dalam menerapkan hukum sesuai kebenaran dan keadilan.

Penegak hukum dimaksud, bukan saja Polisi, Hakim dan Jaksa, tetapi juga Advokat. Peranan Advokat sangat penting dalam penegakkan hukum di negeri ini, sebab advokat memiliki kewenangan dan kemampuan untuk memasuki wilayah- 
wilayah hukum, antara lain: Hukum Perdata, Hukum Pidana, Hukum Administrasi Negara, litigasi maupun non litigasi dalam perkara-perkara perdata lainnya.

Advokat dalam kedudukan sebagai penegak hukum menunjukan eksistensinya dalam turut serta menciptakan/mewujudkan dan memelihara sistem peradilan yang bersih, berwibawa dan beradab demi terwujudnya wibawa hukum di negeri ini. Maka demikian, advokat dalam mewujudkan cita-cita hukum harus memiliki keimanan dan ketaqwaan kepada Allah ta'ala yang kuat dan kokoh serta harus berani tampil bersih dan terlebih dahulu membersihkan diri dari pikiranpikiran kotor ditengah-tengah menjalankan profesi hukum, agar profesi mulia tersebut tidak tercemar menjadi hina akibat pelanggaran norma hukum dan kode etik profesi oleh advokat, karena eksistensi Advokat dalam memberikan nasehat hukum, bantuan hukum dan pembelaan hukum terhadap tersangka/terdakwa pada semua tahap kasus korupsi perlu mendapat perhatian tersendiri, karena bahaya dari tindak pidana korupsi tersebut merusak perekonomian negara dan sendi-sendi kehidupan berbangsa dan bernegara, bahkan dapat membuat negeri bangrut dan berantakan.

Advokat dalam menjalankan profesinya harus tunduk dan patuh kepada Peraturan Perundang-undangan yang berlaku dan menjunjung tinggi kode etik profesi Advokat. Jika ada seorang calon klien dengan membawa sebuah perkara dan kenyataannya perkara tersebut bertentangan dengan hati nurani, maka Advokat berhak menolaknya. Namun dalam sudut pandang yang lainnya seorang Advokat tidak boleh menolak suatu perkara, apabila perkara tersebut memiliki landasan hukum yang jelas.

Kedudukan advokat sebagai penegak hukum tertuang dalam ketentuan Pasal 5 ayat (1) Undang-undang nomor 18 Tahun 2003 tentang Advokat, menegaskan, bahwa Advokat berstatus sebagai penegak hukum, bebas dan mandiri yang dijamin oleh hukum dan peraturan perundang-undangan. Pembelaan Hukum Advokat terhadap
Tersangka/terdakwa merupakan tujuan mulia yaitu menegakkan hukum sesuai keadilan dan kebenaran, karena advokat hakekatnya merupakan suatu profesi terhomat (officium nobile). Pembelaan hukum dimaksud bukan semata-mata membela Tersangka/Terdakwa yang secara nyata benar-benar telah melakukan tindak pidana korupsi, melainkan membela hak hukum tersangka/terdakwa dan mendudukan hukum secara proporsional dan wajar, agar tercapai/terwujud kepastian hukum, kebenaran dan keadilan bagi tersangka/terdakwa yang diduga melakukan tindak pidana korupsi.

Advokat dalam menjalankan profesi terikat dengan kode etik profesi sebagaimana tercantum dalam ketentuan pasal 26 Undang-undang nomor 18 Tahun 2003 tentang Advokat, yaitu: ayat (1) Untuk menjaga martabat dan kehormatan profesi Advokat, disusun kode etik profesi Advokat oleh Organisasi Advokat. (2) Advokat wajib tunduk dan mematuhi kode etik profesi Advokat dan ketentuan tentang Dewan Kehormatan Organisasi Advokat. (3) Kode etik profesi Advokat sebagaimana dimaksud pada ayat (1) tidak boleh bertentangan dengan peraturan perundang-undangan.

Pengawasan atas pelaksanaan kode etik profesi Advokat dilakukan oleh Organisasi Advokat. (5) Dewan Kehormatan Organisasi Advokat memeriksa dan mengadili pelanggaran kode etik profesi Advokat berdasarkan tata cara Dewan Kehormatan Organisasi Advokat. (6) Keputusan Dewan Kehormatan Organisasi Advokat tidak menghilangkan tanggung jawab pidana apabila pelanggaran terhadap kode etik profesi Advokat mengandung unsur pidana. (7) Ketentuan mengenai tata cara memeriksa dan mengadili pelanggaran kode etik profesi Advokat diatur lebih lanjut dengan Keputusan Dewan Kehormatan Organisasi Advokat.

Peran advokat sangat penting dalam sistem peradilan Indonesia, sehingga apabila terjadi penyalahgunaan profesi hukum oleh Advokat, maka harus mendapatkan sanksi yang tegas dan lebih berat dua kali lipat dari pada profesi diluar profesi hukum, karena advokat merupakan 
profesi hukum yang menegakkan hukum secara adil dan benar, bukan merusak tatanan hukum itu sendiri. Disamping itu profesi advokat merupakan profesi mulia nan luas perannnya, dalam hal ini berperan dalam berbagai sektor kehidupan bermasyarakat, berbangsa dan bernegara dengan menjalankan profesi yang bebas dan mandiri, namun memiliki tanggungjawab kepada publik yang mengantungkan harapan untuk mencari keadilan.

Advokat memiliki peran dalam mendidik atau memberi pelajaran ilmu pengetahuan hukum kepada masyarakat agar masyarakat menyadari betapa penting membela dan melindungi hak-hak dasar mereka dihadapan hukum. Demikian pula advokat sebagai salah unsur dari sistem peradilan merupakan salah satu pilar dalam menegakkan supremasi hukum dan HAM di Indonesia.

Profesi Advokat dalam melakukan pembelaan hukum terhadap tersangka/terdakwa harus menjunjung tinggi nilai moral agama, karena nilai moral agama memiliki kemampuan untuk mengendalikan emosi advokat dari tindakan melanggar etika profesi dalam melakukan pembelaan hukum terhadap terdakwa dalam sidang Pengadilan.

Terkait Etika Profesi hukum, Supriadi dalam buku: Etika \& Tanggung Jawab Profesi Hukum di Indonesia, mengatakan, bahwa:

Profesi hukum merupakan salah satu profesi yang menuntut pemenuhan nilai moral dan pengembangannya. Nilai moral itu merupakan kekuatan yang mengarahkan dan mendasari perbuatan luhur. Setiap profesional dituntut supaya memiliki nilai moral yang kuat.... ${ }^{1}$

Lebih lanjut Supriadi mengutip Franz Magnis Suseno, mengemukakan, bahwa:

Lima kriteria nilai moral yang kuat yang mendasari kepribadian profesional hukum, kelima kriteria tersebut yaitu:

1. Kejujuran adalah dasar utama. Tanpa kejujuran maka profesional hukum mengingkari nilai profesinya, sehingga

${ }^{1}$ Supriadi, Etika \& Tanggungjawab Profesi Hukum di Indonesia, SINAR GRAFIKA 2006 dia menjadi munafik, licik, penuh tipu diri. Dua sikap yang terdapat dalam kejujuran, yaitu ;

a) sikap terbuka, yaitu berkenaan dengan pelayanan klien, kerelaan secara bayaran atau secara Cumacuma;

b) sikap wajar, ini berkenaan dengan perbuatan yang tidak berlebihan, tidak otoriter, tidak sok kuasa, tidak kasar, tidak menindas dan tidak memeras.

2. Autentik artinya menghayati dan menunjukan diri sesuai dengan keasliannya, kepribadian yang sebenarnya. Otentiknya pribadi profesional hukum antara lain:

a) Tidak menyalahgunakan wewenang;

b) Tidak melakukan perbuatan yang merendahkan martabat (melakukan perbuatan tercela;

c) mendahulukan kepentingan klien;

d) Berani berinisiatif dan berbuat sendiri dengan bijaksana, tidak semata-mata menunggu atasan;

e) tidak mengisolasi diri dari pergaulan sosial.

3. Bertanggungjawab dalam menjalankan tugasnya, profesioal hukum wajib bertanggung jawab, artinya:

a) Kesediaan melakukan dengan sebaik mungkin tugas apa saja yang termasuk lingkup profesinya;

b) bertindak secara profesional, tanpa membedakan perkara bayaran dan perkara Cuma-Cuma (Prodeo);

c) Kesediaan memberikan laporan pertanggungjawab atas pelaksanpelaksanaan

kewajibannya.

4. Kemandirian moral, artinya tidak mudah terpengaruh atau tidak mudah mengikuti pandangan moral yang terjadi di sekitarnya, melainkan membetuk penilaian dan mempunyai pendirian sendiri. mandiri secara moral berarti tidak dapat dibeli oleh pendapat mayoritas, tidak terpengaruhi oleh pertimbangan untung rugi (pamrih), 
penyesuaian diri dengan nilai kesusilaan dan agama.

5. Keberanian moral, adalah kesetiaan terhadap suara hati nurani yang menyatakan kesediaan untuk menanggung resiko konflik.

Keberanian tersebut antara lain:

a) Menolak segala bentuk korupsi, kolusi suap, pungli;

b) Menolak segala bentuk cara penyelesaian melalui jalan belakang yang tidak sah (2)...

\section{B. Permasalahan}

Pemikiran Magnis Suseso yang dikutip Supriadi mengenai kriteria moral Profesi hukum tersebut di atas, merupakan gambaran singkat yang semestinya diteladani oleh advokat dalam menjalankan profesi hukum selaku penegak hukum. Sehingga melahirkan generasi-generasi advokat baru tangguh yang memiliki nilai moral dalam mewujudkan keadilan dan kebenaran. Maka dengan demikian yang menjadi statemen problem dalam penelitian ini adalah Peranan Advokat dalam membela Terdakwa Korupsi di Pengadilan Tindak Pidana Korupsi pada Pengadilan Negeri Samarinda (Tinjauan Etika Profesi Hukum) dan faktor penyebab terjadinya pelanggaran Kode Etik Profesi Hukum oleh advokat.

\section{Tujuan dan Manfaat Penelitian}

Adapun penelitian ini bertujuan untuk mengetahui peranan Advokat dalam pembelaan hukum terhadap terdakwa korupsi pada pengadilan Tindak Pidana Korupsi pada Pengadilan negeri samarinda.

Untuk mengetahui dan mengkaji kemungkinan terjadinya penyuapan oleh Advokat kepada Hakim dalam rangka meringankan atau membebaskan terdakwa korupsi.

Penelitian ini diharapkan bermanfaat baik untuk akademisi yaitu sebagai bahan kajian ilmiah dan menambah khasanah ilmu hukum pengetahuan dan bagi pemerintahan bahwa profesionalisme, tanggungjawab moral dan kejujuran Advokat dibutuhkan dalam penegakan hukum, bahwa profesionalisme dan kemandirian hakim sangat penting dalam penegakan hukum dan terciptanya keterbukaan informasi publik dalam penegakkan hukum, akan melahirkan peradilan yang bersih, adil dan bertanggungjawab.

\section{METODE PENELITIAN}

Penelitian ini merupakan Penelitian pendekatan empiris yaitu hukum sebagai kenyatan sosial, kultural atau desaign, karena dalam penelitian ini digunakan data primer yang diperoleh dari lapangan. Pendekatan yuridis adalah hukum dilihat sebagai norma atau das sollen, karena dalam membahas permasalahan penelitian ini menggunakan bahan-bahan hukum baik hukum yang tertulis maupun hukum yang tidak tertulis atau baik bahan hukum primer maupun bahan hukum sekunder. Jadi, pendekatan yuridis empiris dalam penelitian ini maksudnya adalah bahwa dalam menganalisis permasalahan dilakukan dengan cara memadukan bahanbahan hukum (yang merupakan data sekunder data primer yang diperoleh di lapangan yaitu tentang Peranan Advokat dalam pembelaan hukum terhadap Terdakwa Korupsi di Pengadilan Tindak Pidana Korupsi pada Pengadilan Negeri Samarinda (Tinjauan Etika Profesi Hukum). Data dalam penelitian ini bersumber dari Data primer yang merupakan data yang diproleh secara langsung dari pengamatan atas obyek atau permasalahan yang penulis amati di lokasi penelitian yaitu melalui wawancara langsung dengan pihak-pihak yang bersangkutan dan berkompeten dalam bidang yang berhubungan dengan permasalahan yang di angkat yakni yang berkaitan dengan Peranan Advokat dalam pembelaan hukum terhadap Terdakwa Korupsi di Pengadilan Tindak Pidana Korupsi pada Pengadilan Negeri Samarinda (Tinjauan Etika Profesi Hukum). Data Sekunder adalah data yang diperoleh dari peraturan perundang-undangan studi kepustakaan terhadap jurnal, artikel dalam majalah atau sumber-sumber lain yang terkait dengan permasalahan yang dibahas dalam penulisan ini. Dan Data Tersier

${ }^{2}$ Ibid. Hal. 20 
Adalah bahan hukum yang di peroleh dari Ensiklopedia, Kamus Hukum dan lain-lain. Teknik pengumpulan data yang digunakan dalam penelitian ini dengan melakukan wawancara kepada narasumber terkait pada penelitian, studi Kepustakaan yaitu mempelajari dan mengkaji perundang-undangan, jurnal, literatur, atau dokumen-dukumen yang berkaitan dengan Peranan Advokat dalam pembelaan hukum terhadap Terdakwa Korupsi di Pengadilan Tindak Pidana Korupsi pada Pengadilan Negeri Samarinda (Tinjauan Etika Profesi Hukum).

Teknik Sampling dalam penelitian ini adalah teknik pengambilan sampel yang memberikan peluang yang sama bagi setiap unsur (anggota) populasi untuk dipilih menjadi anggota sampel. Syarat utama probability sampling dilakukan adalah sample diambil dari populasi yang homogen. Ramdom samping atau dalam bahasa indonesia juga Rambang hendaknya memberikan gambaran bahwa distribusi data pada populasi akan berlaku secara sembarang pada setiap anggota dari populasi. Khususnya Simple Random Sampling Dikatakan simple (sederhana) karena pengambilan anggota sample dari populasi dilakukan secara acak tanpa memperhatikan strata yang ada dalam populasi itu. Cara demikian dilakukan bila anggota populasi dianggap homogen atau memiliki kesamaan. Dengan demikian, anggota populasi yang dipilih akan mampu mewakili kondisi populasi. Karena itulah peneliti menggunakan teknik ini sebagai acuan dalam menggambil sampel.

Analisis data dalam penelitian ini yaitu secara deskriptif kualitatif. Deskriptif kualitatif artinya menggambarkan secara jelas dan sistematis seluruh data yang telah diperoleh dan kemudian akan dianalisis terhadap kebutuhan hukum dalam hal implementasi perencanaan pembangunan desa dan kemudian data tersebut akan disajikan dengan memberikan komentarkomentar.

\section{HASIL PENELITIAN \\ DAN \\ PEMBAHASAN}

\section{A. Hasil Penelitian}

Tindak pidana korupsi adalah sebuah kejahatan yang merugikan perekonomian dan keuangan negara, bahkan membuat negara bangkrut dan hancur, karena dashyatnya kejatahan korupsi ini. Meskipun Koruptor adalah jelas-jelas penjahat yang merugikan keuangan dan perekonomian negara, tapi mereka memiliki persamaan hak di mata hukum. Artinya pelaku korupsi berhak atas pembelaan dan/atau perlindungan hukum dari negara melalui LBH secara prodeo maupun didampingi advokat secara komersil. Hak terdakwa untuk mendapatkan bantuan hukum dan/atau bantuan dari Advokat untuk membela kepentingan hukum terdakwa tersebut merupakan bagian dari penghormatan atas hak asasi manusia. Perlindungan terhap hak asasi manusia.

Kehadiran advokat sangat penting dalam membela kepentingan klien (terdakwa) korupsi disidang Pengadilan, agar terlaksananya peradilan yang bersih, adil dan jujur yang dapat dipertangungjawabkan secara hukum dan moral. Advokat sebagai profesi terhormat (officium nobile) dalam menjalankan profesinya harus patuh dan tunduk pada ketentuan hukum yang berlaku dan kode etik profesi Advokat, pandai menjaga harkat dan martabat profesi, serta tidak mudah terpengaruh/terprovokasi dari godaan materi yang membuat profesi advokat menjadi hina dan tidak dipercaya oleh masyarakat.

Profesi advokat merupakan profesi terhormat. Meskpun profesi terhormat tidak sedikit oknum advokat/pengacara yang ditangkap dan jebloskan kedalam penjara oleh Komisi Pemberantasn Korupsi 
(KPK), gara-gara terlibat suap-menyuap perkara korupsi. Advokat berkentingan membela lien (terdakwa), tapi dengan cara terhormat dan mulia sesuai ketentuan hukum yang berlaku dan kode etik profesi advokat serta tidak menggunakan cara-cara kotor yang dapat merugikan profesi advokat itu sendiri.

Belum ditemukan bukti adanya keterlibatan advokat (melanggar kode etik) atau terlibat dalam praktek suap-menyuap kepada hakim atau Jaksa Penuntut Umum (JPU) disidang Pengadilan Tindak Pidana Korupsi pada Pengadilan Negeri. Sehingga untuk membuktikan adanya praktek suapmenyuap (mafia perkara) yang melibatkan hakim, Jaksa Penuntut Umum (JPU) dan Advokat dibutuhkan keberanian semua pihak untuk mengungkap fakta tersebut, termasuk adanya keberanian terdakwa, jika pernah diperas atau jadi korban pemerasaan oleh para penegak hukum. (Hakim, Jaksa, Pengacara).

Peneliti melakukan penelitian pada kantor Pengadilan Negeri Samarinda, Kantor Kejaksaan Negeri Samarinda dan LKBH Univ. Widyagama, kantor Advokat \& Konsultan Hukum MINTON SITUNGKIR \& REKAN. Responden yang dijadikan narasumber utama dalam penelitian ini, yaitu Hakim, Jaksa dan Advokat, yaitu:

\begin{tabular}{|c|c|c|}
\hline No. & N a m a & Profesi \\
\hline 1 & $\begin{array}{c}\text { Burhanudin, } \\
\text { SH.,MH }\end{array}$ & Hakim karier \\
\hline 2 & $\begin{array}{c}\text { Poster Sitorus, } \\
\text { SH.,MH }\end{array}$ & Hakim Ad hoc \\
\hline 3 & $\begin{array}{c}\text { Anggraeni, } \\
\text { SH.,MH }\end{array}$ & Hakim Ad hoc \\
\hline 4 & $\begin{array}{c}\text { Ferry Haryanto. } \\
\text { SH.,MH }\end{array}$ & Hakim Karier \\
\hline
\end{tabular}

\begin{tabular}{|c|c|c|}
\hline 5 & $\begin{array}{c}\text { Joni Kondolele, } \\
\text { SH.,MH }\end{array}$ & Hakim Karie \\
\hline 6 & $\begin{array}{c}\text { Moch. Sochib, } \\
\text { SH }\end{array}$ & JPU \\
\hline 7 & $\begin{array}{c}\text { Dian Angraeni } \\
\text { Kamila, SH }\end{array}$ & JPU \\
\hline 8 & $\begin{array}{c}\text { Sri Rukmini } \\
\text { Setyaningsih, } \\
\text { SH }\end{array}$ & JPU \\
\hline 9 & $\begin{array}{c}\text { Rosnaini Ulfa, } \\
\text { SH }\end{array}$ & JPU \\
\hline 10 & $\begin{array}{c}\text { Abdul Muin Ali, } \\
\text { SH }\end{array}$ & JPU \\
\hline 11 & $\begin{array}{c}\text { Ishak, SH } \\
\text { Indriarasi } \\
\text { Sikapang }\end{array}$ & JPU \\
\hline 12 & $\begin{array}{c}\text { Bayu Fermady, } \\
\text { SH }\end{array}$ & JPU \\
\hline 14 & $\begin{array}{c}\text { Pearlin Rileanta } \\
\text { P. S.S, SH }\end{array}$ & JPU \\
\hline 15 & $\begin{array}{c}\text { Minton } \\
\text { Situngkir, } \\
\text { SH.,MH }\end{array}$ & Advokat \\
\hline 16 & Zakir. Z, SH & Advokat \\
\hline
\end{tabular}

Adapun hasil penelitian, adalah sebagai berikut:

1. Advokat dalam membela kepentingan hukum terdakwa korupsi dilakukan sesuai ketentuan hukum dan Peraturan Perundang-undangan yang berlaku serta menjunjung tinggi kode etik profesi Advokat.

2. Tuntutan Jaksa Penuntut Umum (JPU) dalam perkara tindak pidana korupsi tidak ada tolak ukur yang baku, semua berdasarkan hasil pemeriksaan saksi di persidangan, barang bukti, dan juga keterangan ahli serta keterangan terdakwa.

3. Jaksa Penuntut Umum (JPU) melakukan upaya hukum banding, terhadap putusan Pengadilan Tindak Pidana Korupsi pada Pengadilan Negeri Samarinda, jika putusan tersebut kurang dari 2/3 (dua pertiga) dari tuntutan Jaksa Penuntut Umum (JPU). 
4. Pengadilan Tindak Pidana Korupsi pada Pengadilan Negeri Samarinda pernah memutus perkara pidana korupsi jauh lebih rendah dari tuntutan Jaksa Penuntut Umum (JPU) yaitu seorang terdakwa dituntut 5 (lima) tahun penjara, kemudian oleh Pengadilan Tindak Pidana Korupsi pada Pengadilan Negeri Samarinda memutus perkara tersebut hanya 1 (satu) tahun penjara.

5. Jaksa Penuntut Umum (JPU) menuntut terdakwa Korupsi 14 (empat belas) Tahun penjara, kemudian divonis atau diputus "bebas murni" oleh Pengadilan Tindak Pidana Korupsi pada Pengadilan Negeri Samarinda, kemudian Jaksa Penuntut Umum melakuka upaya hukum kasasi pada Mahkamah Agung.

6. Hakim, Penuntut Umum dan Advokat dalam penanganan perkara tindak pidana korupsi selama ini belum ditemukan fakta adanya pelanggaran hukum maupun kode etik, seperti suap-menyuap (sogok-menyogok).

7. Salah seorang hakim Ad.hoc Tindak Pidana Korupsi mengaku pernah didatangi oleh seorang Advokat yang berusaha menyuap hakim untuk mempengaruhi putusan hakim demi membela kepentingan klien. (Terdakwa), tapi ditolak mentahmentah oleh hakim tersebut.

8. Tidak seorangpun Hakim, Jaksa maupun Advokat yang mengakui secara jujur adanya suap-menyuap (sogok-menyogok) selama menangani perkara tindak pidana korupsi pada Pengadilan Tindak Pidana Korupsi pada Pengadilan Negeri Samarinda.

9. Pengadilan Tindak Tindak Pidana Korupsi pada Pengadilan Negeri Samarinda pernah menjatuhkan putusan terhadap Terdakwa Korupsi jauh lebih ringan dari tuntutan Jaksa Penuntut Umum (JPU).

10. Jaksa Penuntut Umum (JPU) terkadang menuntut ringan terhadap Terdakwa Korupsi.

11. Pengadilan Tindak Pidana Korupsi pada Pengadilan Negeri Samarinda terkadang memutus perkara tindak pidana korupsi jauh lebih tinggi dari tuntutan Jaksa Penuntut Umum (JPU).

\section{B. Pembahasan}

Profesi advokat merupakan profesi yang sangat dibutuhkan oleh para pihak yang sedang bersengketa untuk mendapatkan pelayanan jasa hukum, berupa konsultasi hukum, bantuan hukum, menjalankan kuasa, mewakili, mendampingi, membela dan melakukan tindakan hukum untuk kepentingan klien (Tersangka/Terdakwa) sesuai ketentuan hukum dan Peraturan Perundang-undangan yang berlaku serta kode etik profesi hukum.

\section{Peranan advokat dalam pembelaan hukum terhadap terdakwa korupsi pada pengadilan Tindak Pidana Korupsi pada Pengadilan negeri samarinda (Tinjauan etika profesi hukum) \\ Penegakan hukum (law enforcement)} di Indonesia tidak akan berjalan dengan baik dan benar serta adil, apabila tidak ada advokat yang berperan penting dalam melakukan pembelaan hukum terhadap tersangka/terdakwa, yaitu bertujuan mendudukan pokok permasalahan hukum tersebut benar dan adil. Sebab, jika tidak, bukan suatu hal yang tidak mungkin akan terjadi tindakan kriminalisasi oleh aparat penegkan hukum terhadap seseorang, sehingga terampaslah kemerdekaannya.

Peranan advokat dalam pembelaan hukum terhadap kepentingan terdakwa korupsi dibenarkan oleh hukum dan etik, sepanjang tidak melanggar kaidah/norma hukum, moral dan etik. Pasal 1 butir Undang-undang nomor: 18 Tahun 2003 tentang advokat, menegaskan, bahwa: Advokat adalah orang yang memberikan jasa hukum, baik dalam maupun diluar Pengadilan yang memenuhi persyaratan berdasarkan Undang-undang advokat.

Selain undang-undang advokat, KUHAP juga mengatur peranan advokat dalam melakukan pembelaan hukum terhadap tersangka/terdakwa, sebagaimana dimaksud dalam pasal 54 dan pasal 55, yang menegaskan, bahwa: Guna kepentingan pembelaan, tersangka atau 
terdakwa berhak mendapat bantuan hukum dari seseorang atau lebih penasehat hukum selama dalam waktu dan pada setiap tingkat pemeriksaan, menurut tata cara yang ditentukan dalam undang-undang ini.

Eksistensi Advokat dalam melakukan pembelaan hukum terhadap pihak yang yang memilki kenpetingan pembelaan hukum diatur dalam pasal 115 KUHAP, yang berbunyi, bahwa: ayat (1) Dalam hal penyidik sedang melakukan pemeriksaan terhadap tersangka, penasihat hukum dapat mengikuti jalannya pemeriksaan dengan cara melihat serta mendengar pemeriksaan; (2) Dalam hal kejahatan terhadap keamanan negara penasihat hukum dapat hadir dengan cara melihat tetapi tidak dapat mendengar pemeriksaan terhadap tersangka.

Pernyataan pasal 115 KUHAP tersebut di atas memberikan penegasan, bahwa betapa penting peran dan fungsi advokat/pencara dalam penyidikan, yaitu mengawasi proses penyidikan atas kliennya, sehingga berjalan secara fear, dan terhindar dari potensi adanya rekayasa hukum oleh penyidik yang dapat merugikan klien.

Kehadiran advokat sangat dibutuhkan oleh para pihak yang berperkara (Tersangka/Terdakwa) atau para pihak yang sedang bersengketa hukum. Namun pembelaan hukum oleh advokat harus sesuai koridor hukum yang berlaku, menjunjung tinggi norma agama, moral dan kode etik profesi hukum. Sebab tidak sedikit oknum advokat yang terlibat suapmenyuap kepada hakim maupun Jaksa, kemudian ditangkap oleh Komisi Pemberantasan Korupsi (KPK).

Fakta tersebut tidak terbantahkan, karena ada juga oknum advokat yang menyepelekan kode etik profesi, kemudian gampang melanggarnya hanya untuk menuruti nafsu kenikmatan sesaat. Padahal Profesi Advokat terikat dengan kode profesi pada setiap saat, ketika sedang melakukan pembelaan kepentingan hukum Tersangka/Terdakwa baik didalam maupun diluar pengadilan. Sebab Profesi advokat melekat secara sempurna kode etik yang memiliki nilai dan moral di dalamnya. Siapapun advokat terikat dengan kode etik dan wajib bagi advikat mempatuhinya.
Kode etik Advokat diatur dengan jelas dan tegas dalam Undang-Undang Nomor 18 Tahun 2003 tentang Advokat.

Tim peneliti dari Fakultas Hukum

Universitas Widyagama Mahakam Samarinda melakukan penelitian hukum terkait dengan Peranan Advokat dalam melakukan pembelaan hukum terhadap terdakwa korupsi pada Pengadilan Tindak Pidana Korupsi pada Pengadilan Negeri Samarindar, kantor kejaksaan negeri samarinda, Kantor LKBH Univ. Wdyagama Mahakam Samarinda dan kantor Advokat (Minton Situngkir, SH,MH dan Rekan) untuk menggali informasi terkait Peranan advokat dalam pembelaan hukum terhadap terdakwa korupsi pada pengadilan Tindak Pidana Korupsi pada Pengadilan negeri samarinda (Tinjauan etika profesi hukum).

Peneliti selama melakukan penelitian pada Kantor Pengadilan Negeri Samarinda, Kantor Kejaksaan Nageri Sanmarinda, LKBH Universitas Widyagama Mahakam Samarinda, Kantor Advokat (Minton Situngkir \& Rekan), menemukan beberapa fakta-fakta yang menarik, terkait kemungkinan adanya penyuapan oleh Advokat kepada Hakim dalam rangka meringankan atau membebaskan terdakwa korupsi, antara lain yaitu:

1. Advokat dalam membela kepentingan hukum terdakwa korupsi dilakukan secara professional sesuai ketentuan hukum dan Peraturan Perundangundangan yang berlaku serta menjunjung tinggi kode etik profesi hukum.

2. Tuntutan Jaksa Penuntut Umum (JPU) dalam perkara tindak pidana korupsi tidak ada tolak ukur yang baku, semua berdasarkan hasil pemeriksaan saksi di persidangan, barang bukti, dan juga keterangan ahli serta keterangan terdakwa.

3. Jaksa Penuntut Umum (JPU) melakukan upaya hukum banding, terhadap putusan Pengadilan Negeri Samarinda yang kurang dari $2 / 3$ (dua pertiga) dari tuntutan Jaksa Penuntut Umum (JPU).

4. Pengadilan Negeri Samarinda pernah memutus perkara pidana korupsi jauh 
lebih rendah dari tuntutan Jaksa Penuntut Umum (JPU) yaitu seorang terdakwa dituntut 5 (lima) tahun penjara, kemudian oleh Pengadilan Negeri Samarinda memutus perkara tersebut hanya 1 (satu) tahun penjara.

5. Jaksa Penuntut Umum (JPU) menuntut terdakwa Korupsi 14 (empat belas) Tahun penjara, kemudian divonis bebas murni oleh Pengadilan Negeri Samarinda.

6. Hakim, Penuntut Umum dan Advokat dalam penanganan perkara tindak pidana korupsi tersebut belum ditemukan fakta adanya pelanggaran hukum maupun kode etik, seperti suap-menyuap (sogok-menyogok).

\section{Kemungkinan terjadinya penyuapan oleh Advokat kepada Hakim dalam rangka meringankan atau membebaskan terdakwa korupsi.}

Siapapun tidak ada yang bisa menjamin, bahwa dunia peradilan di Indonesia ini tidak tercemar dari praktek suap-menyuap di antara para penegak hukum (Hakim, Jaksa, Polisi dan Pengacara), namun praktek suap menyuap ini sangat sulit dibuktikan secara hukum, kerena para pelaku adalah orang-orang yang berada didalamnya. Persekongkolan itu sulit dibongkar oleh hukum, kecuali mereka sendiri yang bongkarnya atau operasi tangkap tangan oleh KPK.

Praktek suap-menyuap merupakan tindakan korupsi yang dapat merugikan perekonomian dan keuangan Negara. Biasanya suap-menyuap melibatkan dua pihak (pemberi suap dan penerima suap). Seperti antara hakim dengan pengacara atau hakim dengan terdakwa dibantu oleh Jaksa yang pada akhirnya dari perbuatan tersebut adalah merampok uang Negara. Islam melarang untuk menerima uang suap (uang sogok) atau menyuap orang lain untuk memenankan suatu perkara.
Dari Abdullah bin Amr, dalam sebuah hadist shahih, bahwa Rasulullah shalallahu 'alaihi wasalam: "Melaknat orang yang menyuap dan orang yang menerima suap. Orang yang menyuap dan yang disuap hukumnya sama bagi keduanya, yaitu berdosa. Suap menyuap hukumnya haram, meskipun mereka memakai istilah hadiah, uang terima kasih, dsb. Salah satu dosa besar dalam ajaran agama islam adalah mencuri, yaitu mengambil sesuatu yang bukan miliknya."

KPK menerbitkan buku saku memahami tindak pidana korupsi "memahami untuk membasmi", dalam buku saku tersebut memberikan pemahaman, bahwa cakupan suap adalah (1) Setiap orang, (2) Memberi sesuatu, (3) kepada Pegawai Negeri atau penyelenggara Negara, (4) karena atau berhubungan dengan sesuatu yang bertentangan dengan kewajiban, dilakukan atau tidak dilakuka dalam jabatan.

Undang-undang nomor 20 tahun 2001 tentang Perubahan atas undangundang nomor 31 tahun 1999 tentang pemberantasan korupsi, sebagaimana ditegaskan dalam pasal 5, yang berbunyi: (1) Dipidana dengan pidana penjara paling singkat 1 (satu) tahun dan paling lama 5 (lima) tahun dan atau pidana denda paling sedikit Rp 50.000.000,00 (lima puluh juta rupiah) dan paling banyak $\mathrm{Rp}$ 250.000.000,00 (dua ratus lima puluh juta rupiah) setiap orang yang : a. memberi atau menjanjikan sesuatu kepada pegawai negeri atau penyelenggara negara dengan maksud supaya pegawai negeri atau penyelenggara negara tersebut berbuat atau tidak berbuat sesuatu dalam jabatannya, yang bertentangan dengan kewajibannya; atau $\mathrm{b}$. memberi sesuatu kepada pegawai negeri atau penyelenggara negara karena atau berhubungan dengan sesuatu yang bertentangan dengan kewajiban, dilakukan atau tidak dilakukan dalam jabatannya. 
Ayat (2) Bagi pegawai negeri atau penyelenggara negara yang menerima pemberian atau janji sebagaimana dimaksud dalam ayat (1) huruf a atau huruf $\mathrm{b}$, dipidana dengan pidana yang sama sebagaimana dimaksud dalam ayat (1)

Meskipun perangkat hukum (Per-uu) sudah cukup memadai untuk menjerat pelaku yang merampok uang negara, tapi faktanya penjahat berdasi tersebut justru tumbuh subur di Negara ini. Terlebih-lebih lagi Mahkamah Agung RI memutuskan untuk mengabulkan gugatan uji materi pasal 4 ayat 3 Peraturan KPU Nomor 20 tahun 2018. Ketentuan yang dibatalkan MA tersebut mengatur larangan terhadap eks narapidana (napi) korupsi, mantan napi bandar narkoba dan eks napi kejahatan seksual pada anak menjadi calon legislatif (Vide putusan Mahkamah Agung RI Nomor: $\quad 45 / H U M / 2018)$. Sehingga pemberantasan tindak pidana korupsi dinegeri ini terkesan tidak serius.

Tim peneliti dari Fakultas Hukum Universitas Widyagama Mahakam Samarinda melakukan penelitian hukum terkait dengan Peranan Advokat dalam melakukan pembelaan hukum terhadap terdakwa korupsi pada Pengadilan Tindak Pidana Korupsi pada Pengadilan Negeri Samarindar, kantor kejaksaan negeri samarinda, Kantor LKBH Univ. Wdyagama Mahakam Samarinda dan kantor Advokat (Minton Situngkir, SH,MH dan Rekan) untuk menggali informasi terkait adanya kemungkinan terjadinya penyuapan oleh Advokat kepada Hakim dalam rangka meringankan atau membebaskan terdakwa korupsi.

Peneliti selama melakukan penelitian pada Kantor Pengadilan Negeri Samarinda, Kantor Kejaksaan Nageri Samarinda, LKBH Universitas Widyagama Mahakam Samarinda, Kantor Advokat (Minton Situngkir \& Rekan), menemukan beberapa fakta-fakta yang menarik, terkait kemungkinan adanya penyuapan oleh Advokat kepada Hakim dalam rangka meringankan atau membebaskan terdakwa korupsi, antara lain yaitu:

1. Salah seorang hakim Ad.hoc Tindak Pidana Korupsi mengaku pernah didatangi oleh seorang Advokat yang berusaha menyuap hakim untuk mempengaruhi putusan hakim demi membela kepentingan klien.

2. Tidak seorangpun Hakim, Jaksa maupun Advokat yang mengakui secara jujur adanya suap-menyuap (sogok-menyogok) selama dalam menangani perkara tindak pidana korupsi.

3. Fakta hukum, sering terjadi putusan Pengadilan Negeri Samarinda yang jauh lebih ringan dari tuntutan Jaksa Penuntut Umum (JPU).

4. Jaksa Penuntut Umum (JPU) terkadang menuntut ringan terhadap Terdakwa Korupsi.

5. Pengadilan Negeri Samarinda terkadang memutus perkara tindak pidana korupsi jauh lebih tinggi dari tuntutan Jaksa Penuntut Umum (JPU).

\section{PENUTUP \\ KESIMPULAN DAN SARAN}

Adapun kesimpulan dalam penelitian ini bahwa Peranan advokat sangat penting dalam melakukan pembelaan hukum terhadap kepentingan hukum klien (Terdakwa korupsi), sepanjamg dilakukan secara proporsional dan professional sesuai ketentuan hukum dan Peraturan Perundangundangan yang berlaku, tidak melanggar hukum dan harus benar-benar menjunjung tinggi kode etik profesi hukum.

Kemungkinan terjadinya potensi suap-menyuap (sogok-menyogok) antara Hakim dengan Advokat dan dibantu oleh Jaksa Penuntut Umum dalam penanganan tindak pidana Korupsi pada Pengadilan Tindak Pidana Korupsi pada Pengadilan Negeri Samarinda sangat berpotensi dan terbuka lebar, tapi sangat sulit ditemukan bukti yang cukup tentang adanya suapmenyuap (sogok-menyogok) tersebut. Hal 
ini dikuatkan dengan adanya pengakuan salah seorang hakim Ad.hoc Tindak Pidana Korupsi, bahwa hakim yang bersangkutan mengaku pernah didatangi oleh seorang Advokat yang berusaha menyuap hakim untuk mempengaruhi putusan hakim demi membela kepentingan klien.

Saran yang dapat diberikan dalam penelitian ini yaitu Advokat/Penasehat Hukum dalam melaksanakan tugas profesi melakukan pembelaan hukum terhadap klien (terdakwa) sebaiknya patuh dan taat terhadap hukum dan Peraturan Perundangundangan yang berlaku serta menjunjung tinggi kode etik profesi hukum.

Apabila ada salah seorang oknum advokat yang terbukti melakukan pelanggaran hukum dengan cara menyuap hakim dan/atau Jaksa, sebaiknya diberi sanksi berat sesuai hukum yang berlaku dan diberi sanksi organisasi oleh Pimpinan Organisasi Advokat.

\section{DAFTAR PUSTAKA}

\section{Buku/Literatur}

Rasjidi Lili, Rasjidi Thania, 2002 Pengantar Filsafat Hukum, Bandung Mandar Maju

Supriadi, 2010 Etika \& Tanggungjawab Profesi Hukum di Indonesia, Jakarta. Sinar Grafika

Soekanto Soerjono. (2004), Faktor-faktor yang mempengaruhi Penegakan Hukum, Penerbit RajaGrafindo Persada, Jakarta.

\section{Peraturan Perundang-Undangan}

Undang-Undang Dasar 1945

Undang-undang Nomor 18 Tahun 2003 Tentang Advokat

Undang-undang Nomor 48 Tahun 2009 Tentang Kekuasaan Kehakiman

Undang-undang Nomor 31 Tahun 1999 Jo. Undang-undang Nomor 20 Tahun 2011 Tentang Pemberantasan Tindak Pidana Korupsi

Undang-undang Nomor 15 Tahun 2004 Tetang Pemeriksaan Pengelolaan Dan Tanggung Jawab Keuangan Negara

Undang-undang Nomor 1 Tahun 2004 Tentang Perbendaharaan Negara

Undang-undang Nomor 15 Tahun 2006 Tentang Badan Pemeriksa Keuangan 